\title{
Implementation of Cognitive Theory in Developing Measurement Learning Multimedia for Deaf Students
}

\author{
I Made Suarsana ${ }^{1 *}$, I Gde Wawan Sudatha ${ }^{2}$, Gusti Ayu Mahayukti ${ }^{3}$, I Wayan Edy Ari \\ Suandana ${ }^{4}$, I Gusti Putu Suharta ${ }^{5}$ (iD \\ 1,2,3,4,5 Universitas Pendidikan Ganesha, Singaraja, Indonesia \\ *Corresponding author: made.suarsana@undiksha.ac.id
}

\begin{abstract}
The implementation of cognitive theory in multimedia development for deaf students (students with visual channels only) would be re-examined for its effectiveness. This study aimed to develop mathematics-learning multimedia based on cognitive theory for deaf students on "measurement". This development study adopted the 4D (define, design, develop, disseminate) study design. This study focused on determining the media feasibility based on expert validation, practicality trials, and effectiveness in the first year. The subjects of this study were 4 experts (content expert, learning design expert, media expert, and linguist), 2 teachers, and 7 students. The media feasibility data were collected with validation sheets, questionnaires, and tests. Furthermore, the data were analyzed using descriptive statistics. Based on the results, the feasibility level based on material experts, media experts, learning design experts, and linguists were 93.3\%, 96.7\%, 90\%, and $93.3 \%$, so it could be said that the developed multimedia met validity criteria. Based totally on the consequences, the multimedia practicality test for teachers and students were $95 \%$ and $93 \%$ respectively so that it could be said that multimedia met the practical criteria and the average percentage of student material mastery was $80.1 \%$ with passing grade of $71.4 \%$ so it could be said that multimedia met the effective criteria. Since the multimedia met the valid, practical, and effective criteria, it could be said that multimedia is feasible for learning.
\end{abstract}

Keywords: Multimedia, Cognitive Theory, Deaf, Mathematics

$\begin{array}{ll}\text { History: } & \\ \text { Received } & \text { : August 19, } 2021 \\ \text { Revised } & \text { : August 20, 2021 } \\ \text { Accepted } & \text { : September 20, } 2021 \\ \text { Published } & \text { : October 25, 2021 }\end{array}$

Published : October 25, 2021

\section{INTRODUCTION}

Mathematics is one of the compulsory subjects for deaf students (DS). In general, mathematics learning for DS aims to equip students with the ability of concept comprehension, reasoning and communication, connection, and mathematical problem solving to support them in daily life, work, family, and society (Suarsana et al., 2021; Syafrudin \& Sujarwo, 2019). Mathematics learning outcomes of DS are nonetheless low and far behind as compared to normal students. For normal students, mathematics is a subject that is considered difficult. For DS, the hassle will become even greater complicated due to hearing loss. Limitations to studying for DS encompass weak access to information, restrained conversation with instructors or different students, low mastering motivation, and sometimes frustration in expressing ideas or questions (Hasmayati, 2016; Rahmah, 2018; Suarsana, 2021).

Mathematics learning for DS certainly cannot be equated with normal students. Two things that need attention are the characteristics of DS and the characteristics of mathematics. DS is frequently known as visible learners due to the fact they soak up greater knowledge by way of seeing and experience limitations in receiving auditive information (Hutami et al., 2014; Malatista \& Sediyono, 2010). The limited listening ability in deaf students is often followed by articulation difficulties that make it difficult to communicate. With a small vocabulary, the teacher must convey the teaching material clearly and consistently 
(Anindyajati \& Choiri, 2017; Habibi, 2017; Kusumawati et al., 2017). Therefore, teaching materials should use simple language and be equipped with visual representations. Meanwhile, mathematics is learned with un-concrete ideas (Sabirin, 2014). Therefore, the illustration of the mathematics concept must also be performed simply and represent various and consistent visualizations. Visualization in mathematics learning can be performed with concrete objects, manipulative models, pictures, animations, videos, and computer simulations. With the advancement of information technology today, everything can be packaged as learning multimedia.

The use of multimedia as a learning medium is a current trend, even for students, multimedia has become the second learning preference after teachers (Salsidu et al., 2018). Some of the advantages of multimedia learning are (1) generating student motivation, (2) learning becomes more interesting and interactive, (3) being able to involve more senses, (4) more realistic learning, and (5) increasing student learning independence (Laksana, 2017; Tamami et al., 2020). Multimedia learning for DS is still rare, especially for mathematics. One of the bases in developing multimedia learning is cognitive theory. The basis used in developing multimedia is the cognitive theory which has been empirically proven to be effectively applied in normal student learning, namely students with audio and visual information channels.

However, the implementation of cognitive theory in multimedia development for deaf students (students with visual channels only) would be re-examined for its effectiveness. Several multimedia studies for DS, namely (Putri et al., 2020) developed sign language learning multimedia, (Effendi et al., 2016) developed learning multimedia about breathing for SDLB, (Pariyatin \& Ashari, 2014) developed VII-grade civic studies learning multimedia, and (Yuliana \& Supraptono, 2016) developed Indonesian language learning multimedia. For mathematics learning, multimedia for DS is still very limited such as developed VII -grade mathematics learning multimedia, developed IV-grade mathematics learning multimedia (Beni et al., 2017; Putra et al., 2020; Salim, 2016; Suarcita et al., 2020; Suarsana et al., 2018; Sumalasia et al., 2020).

In those studies, the influence of cognitive theory has not been clearly stated, even though in developing multimedia. Because of that, several principles need to be studied in depth according to the special needs of DS. Therefore, in developing interactive multimedia, the presence of text or speaker images needs to appear on the screen, which of course is not in line with the two principles above. Through this study, the implementation of cognitive theory would be revealed empirically. The novelty of this study lies in the improvement of cognitive theory in learning multimedia applied to DS. Thus, the problem state is the feasibility of mathematics learning multimedia based on cognitive theory for deaf students in terms of validity, practicality, and effectiveness.

\section{METHODS}

This study adopted 4-D (define, design, develop, and disseminate) (Laili et al., 2019; Weriyanti et al., 2020). In the define stage, the identification of problems in the field was carried out related to mathematics learning for deaf students, namely (1) the mathematics learning achievement of students was still low, especially in "measurement". Students had difficulties in recognizing, comparing, and taking measurements related to length. Students were still constrained in the prerequisite material related to decimal fractions. (2) Learning media is still minimal so that the teachers dominate learning with the lecture method using total communication, which often makes teachers and students tired quickly. At this stage, the analysis was carried out also on the characteristics of deaf students, namely (1) visual learners, (2) limited language skills, (3) sensitive, and (4) low intelligence development. 
In the design stage, the multimedia design considers the characteristics of the material, the principles of cognitive theory, as well as interactivity by compiling a storyboard before it is compiled into an initial multimedia draft or prototype 1 . The multimedia material developed was "measurement" material for VIII-grade. The characteristics of the multimedia design are (1) the presentation of material based on learning videos equipped with sign language, (2) the implementation of Mayer's cognitive theory, (3) hierarchical material order, (4) interactive, and (5) equipped with formative tests with direct feedback. To implement the prototype of multimedia, several applications such as Powtoon and Adobe Premiere Pro were used for creating the animation and editing of learning videos, as well as Articulate Storyline for authoring tools as interactive multimedia applications.

The development stage aimed to produce a final multimedia prototype by conducting a draft feasibility test and improvement. The expert validity test involved four people, namely material experts, media experts, learning design experts, and linguists. The user feasibility test was conducted by 2 teachers and 7 students at SLB Negeri 1 Klungkung. The dissemination stage is performed by conducting extensive testing of the multimedia prototype, revising, and disseminating the final product so it could be established through users. However, this study is restricted to the development stage. There were three main data related to the multimedia feasibility namely validation, practicality, and effectiveness. Each of them was collected with validation sheets, questionnaires, and tests. Corrective inputs from experts and users in the form of qualitative data were directly used to improve multimedia, while quantitative data were analysed with descriptive statistics and converted into Table 1 and Table 2. Multimedia was categorized as valid if the mean score was greater than 78.7 , categorized as practical if the mean score was greater than 68 , and categorized as effective if the mean test score was at least 72 with a classical passing grade greater than $70 \%$.

Table 1. Validity Criteria (Suarsana et al., 2018)

\begin{tabular}{cc}
\hline Interval & Category \\
\hline $78.7 \leq \bar{S} \leq 100$ & Valid \\
$56 \leq \bar{S}<78.7$ & Fairly Valid \\
$33.3 \leq \bar{S}<56$ & Invalid \\
\hline
\end{tabular}

Table 2. Practicality Criteria (Kharisma \& Asman, 2018)

\begin{tabular}{cc}
\hline Interval & Category \\
\hline $85 \leq \bar{S} \leq 100$ & Very High \\
$68 \leq \bar{S}<84$ & High \\
$52 \leq \bar{S}<68$ & Medium \\
$36 \leq \bar{S}<52$ & Low \\
$20 \leq \bar{S}<36$ & Very Low \\
\hline
\end{tabular}

\section{RESULTS AND DISCUSSION}

\section{Results}

This multimedia consists of 5 main menus, namely learning objectives, materials, simulations, exercises, and evaluations. When the multimedia is run it will be taken to the front page preceded by the intro. After pressing the START button, the user is directed to the main menu page with 5 menu options, namely the "Competency", "Material", "Simulation", "Training", and "Evaluation" buttons. The "Competency" menu page will display the basic competencies and learning objectives within the scope of this multimedia. The 
"MATERIAL" menu page contains 3 sub-menus, namely an introduction page to prepare users to enter the core material, a learning video page which in its production pays great attention to Mayer's cognitive theory equipped with sign language, and a summary page to display the material summary.
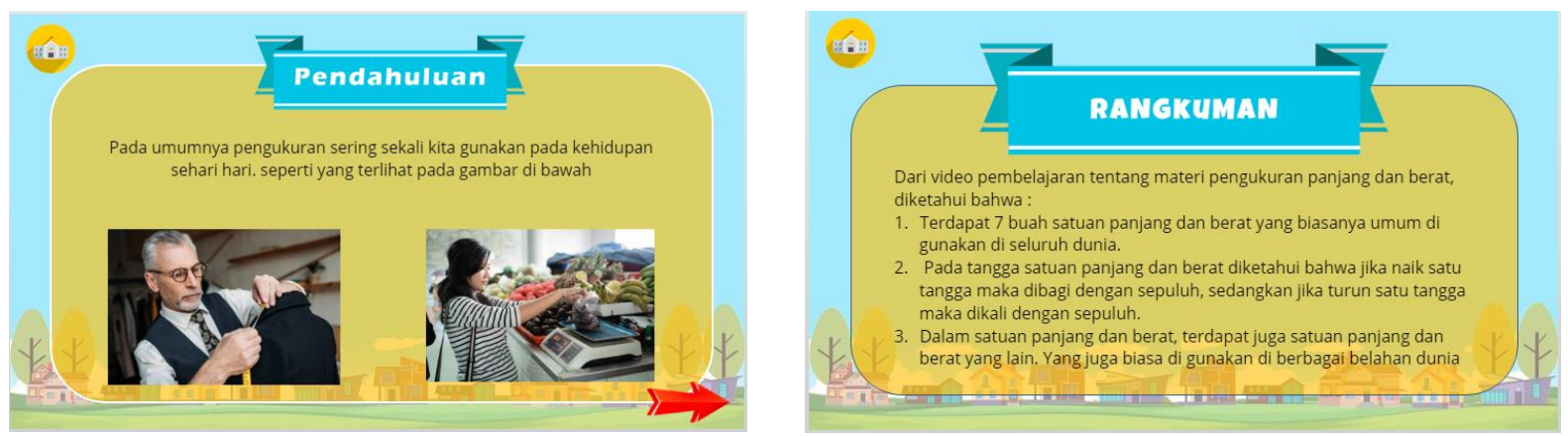

Figure 1. Learning Material Menu Preview

This multimedia is also equipped with a "simulation" menu so that students can take measurements of length and weight virtually. Students can manipulate the media by comparing a quantity (length or weight) with their respective measuring tools such as rulers and virtual scales. There is also an "Exercise and Evaluation" menu to measure the mastery level. The response given to answers in working on questions is direct and immediate. There are 3 criteria set so that the multimedia developed is said to be feasible, namely valid, practical, and effective according to the following Table 3.

Table 3. Multimedia Feasibility Evaluation Result

\begin{tabular}{|c|c|c|c|c|c|}
\hline Validity & $\begin{array}{c}\text { Score/ } \\
\text { Category }\end{array}$ & Practicality & $\begin{array}{c}\text { Score/ } \\
\text { Category }\end{array}$ & Effectiveness & $\begin{array}{c}\text { Score/ } \\
\text { Category }\end{array}$ \\
\hline 1. Material & 93.3 (Valid) & \multirow{2}{*}{ 1. Teachers } & 95 & 1. Average & \multirow{2}{*}{80.1} \\
\hline 2. Media & 96.7 (Valid) & & (Practice) & Score & \\
\hline 3. Learning & 90 (Valid) & \multirow{2}{*}{ 2. Students } & 93 & 2. Passing & \multirow[t]{2}{*}{ Effective } \\
\hline $\begin{array}{l}\text { Design } \\
\text { 4. Language } \\
\end{array}$ & 93.3 (Valid) & & (Practice) & $\begin{array}{l}\text { Grade } \\
(\%)\end{array}$ & \\
\hline
\end{tabular}

The assessment results of learning multimedia materials obtained a score of 93.3 so that it is considered valid. The assessment results of learning media obtained a score of 96.7 so that it is considered valid. The results of the learning design assessment obtained a score of 90 so that it is considered valid. The language assessment results on multimedia obtained a score of 93.3 so that it is considered valid. It can be concluded that the developed multimedia is suitable to be implemented in the learning process.

\section{Discussion}

The multimedia described in the results was a revised draft based on expert and user input. The main inputs from material experts were (1) the level of complexity of the material and questions to be lowered considering that deaf students sometimes still have problems with basic arithmetic operations, (2) the material context should be close to daily life, and (3) visualization should not be excessive and consistent to avoid confussion. Apart from language barriers, understanding concepts and arithmetic skills were still the main problems in learning mathematics for deaf students (Fauyan, 2019; Lee \& Osman, 2012). The selection of contexts related to daily life is very relevant to a study that presenting a real-world context 
through a realistic mathematical approach that could improve the mathematics learning achievement of deaf students (Kowiyah et al., 2019; Setiyani et al., 2020).

The inputs from media experts were mainly related to the implementation of cognitive theory including (1) text, images, sound, video to make it more simple and interesting, (2) sign language narration with animation or video so that it could appear simultaneously, (3) pointing to the important material or objects, (4) segmenting the material per learning indicator, (5) long or complex presentations should not be presented with text but demonstrated in sign language accompanied with a picture or video illustrations. In developing multimedia for normal students (students with two channels of information, namely audio and visual), the foundation used is generally Mayer's cognitive theory (Jabar \& Ahmad, 2018; Khamparia \& Pandey, 2017; Komalasari \& Rahmat, 2019). The implementation of cognitive theory in developing multimedia for deaf students (students with one channel, namely visual) in the form of learning videos with animation content, images, texts, sign language translators have been proven to make it less complicated for students to understand the content (Hidayat et al., 2017; Indah Septiani et al., 2020; Primamukti \& Farozin, 2018).

The inputs from the learning design expert were (1) the material must be in order, (2) the presentation should be in order from top to bottom, not sideways or crosswise, (3) learning objectives and summaries must be included, (4) learning instructions must be completed. Regarding the language aspect, the inputs from linguists were (1) use simple sentences and avoid compound sentences, (2) use vocabulary consistently to propose the same object, and (3) sign language display need to be enlarged to make it clear for the students. Feedbacks from teachers were (1) enlarge the multimedia display or full screen, (2) use an easy-to-read printed typeface, (3) practice questions should be arranged from low to high difficulty, while feedback from students can be observed from their enthusiasm in trying media where deaf students are very interested in learning videos and virtual measuring activities provided on the simulation menu. The main obstacles in deaf student learning are language and communication skills (Hasmayati, 2016; Hutami et al., 2014; Rahmah, 2018; Winarsih, 2013). Therefore, the multimedia delivery language should be made as simple as possible by avoiding idioms (bin Abdul Samat \& Abdul Aziz, 2020; Liang et al., 2011).

The results of the quantitative feasibility assessment are listed in Table 3. Based on expert assessment scores, user response scores, and test scores, the multimedia developed was in the FEASIBLE category because it met the valid, practical, and effective criteria. The four experts (material experts, media experts, learning design experts, and linguists) gave a score of more than $78.1 \%$ that means the multimedia met validity criteria. This is in line with a study about the use of multimedia in learning mathematics for deaf students that make it less complicated for students to reach the material and increase learning motivation (Beni et al., 2017; Putra et al., 2020; Suarcita et al., 2020; Suarsana, 2021; Suarsana et al., 2018; Sumalasia et al., 2020). Evaluation of multimedia effectiveness was measured using a test involving a small group of 7 people with an average score of 80.1 with a passing grade of $71.4 \%$. The results of this limited trial served as initial information indicating that multimedia developed in addition to being able to motivate students to learn can also help students to make it easier to reach the learning goal. This can be seen from the average score of 72 . With these results, it can be said that the multimedia met the effectiveness criteria. The implementation of multimedia in learning for deaf students is effective in enhancing student learning achievement (Majid et al., 2012; Suarsana et al., 2019).

Thus, this study successfully developed a mathematics learning multimedia prototype for deaf students on "measurement" material with a feasible category. Experts and users agreed that multimedia can be used to support mathematics learning for deaf students. This is certainly a solution to the limitations of multimedia mathematics learning for currently 
available deaf students, which is of course very much needed, especially in distance learning during the COVID-19 pandemic (Margarita et al., 2018; Marnita \& Ernawati, 2017; Riyanto \& Gunarhadi, 2017). This multimedia can be regarded as an improvement in mathematics learning multimedia for deaf students (Beni et al., 2017; Suarsana et al., 2018). Which could only be run with Windows/Mac/Linux OS, so it means that the multimedia could also be run on Android or iOS. The developed multimedia is very concerned about the application of Mayer's cognitive theory. The next stage is a large trial involving a wider range of subjects that requires to be carried out immediately to obtain proof that the use of multimedia can improve the mathematics learning achievement of deaf students. The limitation of this study is that wide-field experiments have not been carried out to test the effectiveness of multimedia in improving student learning outcomes. Other researchers are recommended to conduct more in-depth experimental research in investigating the effect of applying the principles of cognitive theory on deaf students, especially about the redundancy principle and the image principle.

\section{CONCLUSION}

Multimedia learning mathematics for deaf students based on cognitive theory met valid, practical, and effective criteria. In its development, this multimedia pays great attention to Mayer's cognitive theory so that the cognitive load is not excessive and in line with the characteristics of deaf students.

\section{REFERENCES}

Anindyajati, Y. R., \& Choiri, A. S. (2017). The effectiveness of using Wordwall Media to increase science-based vocabulary of students with hearing impairment. European Journal of Special Education Research, 2(2), 1-13. https://doi.org/10.5281/zenodo.236877.

Beni, K., Gita, I. N., \& Suarsana, I. M. (2017). Media Pembelajaran Matematika Interaktif untuk Siswa Tunarungu: Perancangan dan Validasi. Seminar Nasional Pendidikan Teknik Informatika Senapati, 0711, 16-22. https://eproceeding.undiksha.ac.id/index.php/senapati/article/view/1144/858.

bin Abdul Samat, M. S., \& Abdul Aziz, A. (2020). The Effectiveness of Multimedia Learning in Enhancing Reading Comprehension Among Indigenous Pupils. Arab World English Journal, 11(2), 290-302. https://doi.org/10.24093/awej/vol11no2.20.

Effendi, D., Hardiyana, B., \& Gustiana, I. (2016). Perancangan program aplikasi pembelajaran ipa materi sistem pernapasan berbasis multimedia untuk siswa sdlb bagian b tuna rungu menggunakan object oriented approach. Simetris: Jurnal Teknik Mesin, Elektro Dan Ilmu Komputer, 7(2), 605-618. https://doi.org/10.24176/simet.v7i2.773.

Fauyan, M. (2019). Developing Interactive Multimedia Through Ispring on Indonesian Language Learning with The Insights of Islamic Values in Madrasah Ibtidaiyah. $A l$ $\begin{array}{lllll}\text { Ibtida: Jurnal Pendidikan } & \text { Guru }\end{array}$ https://doi.org/10.24235/al.ibtida.snj.v6i2.4173.

Habibi, N. (2017). The Use of Flashcards in Improving Vocabulary Mastery of Students with Disability. Inklusi Journal Of Disability Studies, 121. https://doi.org/10.14421/ijds.040203.

Hasmayati, E. (2016). Model Komunikasi Orang Tua Tunarungu Yang Memiliki Anak Mendengar. Jurnal Eksistensi Pendidikan Luar Sekolah (E-Plus), 1(2). https://doi.org/10.30870/e-plus.v1i2.1163. 
Hidayat, L., Gunarhadi, G., \& Hidayatulloh, F. (2017). Multimedia based learning materials for deaf students. European Journal of Special Education Research, 2(3), 77-87. https://doi.org/10.46827/ejse.v0i0.575.

Hutami, P. A., Ajisuksmo, C. R. P., \& Tunjungsari, H. (2014). Gambaran Kompetensi Pedagogik Guru Dalam Mengajar Siswa Tunarungu. Widya Dharma: Jurnal Kependidikan, 26(2), 161-182. https://ejournal.usd.ac.id/index.php/widyadharma/article/view/827.

Indah Septiani, A. nisa N. S., Septiani, I., Rejekiningsih, T., Triyanto, \& Rusnaini. (2020). Development of interactive multimedia learning courseware to strengthen students' character. European Journal of Educational Research, 9(3), 1267-1279. https://doi.org/10.12973/eu-jer.9.3.1267.

Jabar, S. A., \& Ahmad, A. (2018). The design of multimedia interactive courseware for teaching reading to hearing impaired students. International Journal of Academic Research in Progressive Education and Development, 7(4). https://doi.org/10.6007/ijarped/v7-i4/4849.

Khamparia, A., \& Pandey, B. (2017). Impact of interactive multimedia in E-learning technologies: Role of multimedia in E-learning. Enhancing Academic Research With Knowledge Management Principles, April, 199-227. https://doi.org/10.4018/978-15225-2489-2.ch007.

Kharisma, J. Y., \& Asman, A. (2018). Pengembangan Bahan Ajar Matematika Berbasis Masalah Berorientasi pada Kemampuan Pemecahan Masalah Matematis dan Prestasi Belajar Matematika. Indonesian Journal of Mathematics Education, 1(1), 34-46. https://doi.org/10.31002/ijome.v1i1.926.

Komalasari, K., \& Rahmat, R. (2019). Living Values Based Interactive Multimedia in Civic Education Learning. International Journal of Instruction, 12(1), 113-126. https://doi.org/10.29333/iji.2019.1218a.

Kowiyah, K., Mulyawati, I., \& Umam, K. (2019). Conceptual Understanding and Mathematical Representation Analysis of Realistic Mathematics Education Based on Personality Types. Al-Jabar: Jurnal Pendidikan Matematika, 10(2), 201-210. https://doi.org/10.24042/ajpm.v10i2.4605.

Kusumawati, P., Sudirman, \& Kusuma, P. I. (2017). the Effect of Digital Flashcard on Students ' Vocabulary Mastery of the Fourth Grade Students At Sd Negeri 1 \& 2 Paket Agung in the Academic Year 2016 / 2017. Jurnal Pendidikan Bahasa Inggris Undiksha, 5(2). https://doi.org/10.23887/jpbi.v5i2.13324.

Laili, Ganefri, \& Usmeldi. (2019). Efektivitas Pengembangan E-Modul Project Based Learning pada Mata Pelajaran Instalasi Motor Listrik. Jurnal Ilmiah Pendidikan Dan Pembelajaran, 3(3). https://doi.org/10.23887/jipp.v3i3.21840. 306-309.

Laksana, S. D. (2017). Improving The Quality Of Learning Mathematics Through Innovative Learning Media. Jurnal Pendidikan Dan Pengajaran, 50(2). https://doi.org/10.23887/jpp.v50i2.11658.

Lee, T. T., \& Osman, K. (2012). Interactive Multimedia Module in the Learning of Electrochemistry: Effects on Students' Understanding and Motivation. Procedia Social and Behavioral Sciences, 46. https://doi.org/10.1016/j.sbspro.2012.05.295.

Liang, Y., Zheng, T., \& Wang, M. (2011). English audio-visual teaching mode and its teaching environment construction - Henan Institute of Science and Technology as the example. 2011 International Conference on Multimedia Technology, 3050-3053. https://doi.org/10.1109/ICMT.2011.6001924.

Majid, M. S. Z. B. A., Ali, M. M. B. A., Rahim, A. A. B. A., \& Khamis, N. Y. B. (2012). The Development of Technical English Multimedia Interactive Module to Enhance Student Centered Learning (SCL). Procedia - Social and Behavioral Sciences, 67, 
345-348. https://doi.org/10.1016/j.sbspro.2012.11.337.

Malatista, B. R., \& Sediyono, E. (2010). Model pembelajaran matematika untuk siswa kelas IV SDLB penyandang tunarungu dan wicara dengan metode komtal berbantuan komputer. 7(1), 219382. Jurnal Teknik Informatika Dan Sistem Informasi, 7(1). https://doi.org/10.6007/ijarped/v7-i4/4849.

Margarita, N., Harjono, N., \& Airlanda, G. S. (2018). Pengembangan Multimedia Interaktif Sebagai Alat Bantu Pembelajaran Dengan Model Pbl Untuk Peningkatan Hasil Belajar Matematika. Journal for Lesson and Learning Studies, 1(3), 243-257. https://doi.org/10.23887/jlls.v1i3.15388.

Marnita, \& Ernawati. (2017). The Use of Interactive Multimedia (Macromedia Flash) to Increase Creative Thinking Ability of Students in Basic Physics Subject. Jurnal Pendidikan Fisika Indonesia, 13(2), 71-78. https://doi.org/10.15294/jpfi.v13i2.10152.

Pariyatin, Y., \& Ashari, Y. Z. (2014). Perancangan media pembelajaran interaktif mata pelajaran PKN untuk penyandang tunarungu berbasis multimedia (Studi Kasus di Kelas VII SMPLB Negeri Garut Kota). Jurnal Algoritma, 11(1). https://doi.org/10.33364/algoritma/v.11-1.1.

Primamukti, A. D., \& Farozin, M. (2018). Utilization of interactive multimedia to improve learning interest and learning achievement of child. Jurnal Prima Edukasia, 6(2), 111-117. https://doi.org/10.21831/jpe.v6i2.19183.

Putra, I. K. A. A. J., Suarsana, I. M., \& Suharta, I. G. P. (2020). Pengembangan Bahan Ajar Interaktif Materi Pecahan Untuk Siswa Smplb Tunarungu Dengan Pendekatan Multi Representasi. Jurnal Nasional Pendidikan Teknik Informatika: JANAPATI, 9(2). https://doi.org/10.23887/janapati.v9i2.23184.

Putri, N. M. L. K., Parmiti, D. P., \& Sudarma, I. K. (2020). Pengembangan Video Pembelajaran dengan Bahasa Isyarat Berbasis Pendidikan Karakter pada Siswa Kelas V di SDLB-B Negeri I Buleleng Tahun Pelajaran 2017/2018. Jurnal EDUTECH Undiksha, 7(2), 81-91. https://doi.org/10.23887/jeu.v7i2.23162.

Rahmah, F. N. (2018). Problematika anak tunarungu dan cara mengatasinya. Quality, 6(1), 115. https://doi.org/10.21043/quality.v6i1.5744.

Riyanto, W. D., \& Gunarhadi, G. (2017). The Effectiveness of Interactive Multimedia in Mathematic Learning: Utilizing Power Points for Students with Learning Disability. IJPTE: International Journal of Pedagogy and Teacher Education, 1(1), 55-63. https://doi.org/10.20961/ijpte.v1i1.8400.

Sabirin, M. (2014). Representasi dalam pembelajaran matematika. Jurnal Pendidikan Matematika UIN Antasari, 1(2), 33-44. https://doi.org/10.18592/jpm.v1i2.49.

Salim, A. (2016). Pembelajaran matematika berbasis komputer dengan metode multikomunikasi untuk siswa kelas IV SDLB-B. Jurnal Informatika, 3(1). https://doi.org/10.31294/ji.v3i1.291.

Salsidu, S. Z., Azman, M. N. A., \& Pratama, H. (2018). Trend pembelajaran menggunakan multimedia interaktif dalam bidang pendidikan teknikal: Satu sorotan literatur. Sains Humanika, 10(3). https://doi.org/10.11113/sh.v10n3.600.

Setiyani, S., Fitriyani, N., \& Sagita, L. (2020). Improving student's mathematical problem solving skills through Quizizz. JRAMathEdu (Journal of Research and Advances in Mathematics Education), 5(3), 276-288. https://doi.org/10.23917/jramathedu.v5i3.10696.

Suarcita, G. P., Astawa, I. W. P., \& Suarsana, I. M. (2020). Development Of Interactive Digital Teaching Materials With A Multi-Representation Approach To Round Number Materials For Vii Class Tunarungu Smplb Students. Akademika: Jurnal Teknologi Pendidikan, 9(01), 69-84. https://uia.e-journal.id/akademika/index.

Suarsana, I. M. (2021). Developing Interactive Digital Mathematics Book with Multi 
Representation Approach for Deaf Students. International Journal of Emerging Technologies in Learning, 16(13). https://doi.org/10.3991/ijet.v16i13.22459.

Suarsana, I. M., Mahayukti, G. A., Sudarma, I. K., \& Pujawan, A. A. G. S. (2019). The Effect of Interactive Mathematics Learning Media toward Mathematical Conceptual Understanding on Probability of Hearing-impaired Students. Journal of Physics: Conference Series, 1165, 012021. https://doi.org/10.1088/1742-6596/1165/1/012021.

Suarsana, I. M., Mahayukti, G. A., Sudarma, K., \& Yoga, N. B. A. (2018). Development of Interactive Mathematics Learning Media on Statistics Topic for Hearing-impaired Student I Made Suarsana a. International Research Journal of Engineering, IT \& Scientific Research, 4(6), 55-66. https://doi.org/10.21744/irjeis.v4n6.377.

Suarsana, I. M., Sudatha, I. G. W., Mahayukti, G. A., \& Apsari, R. A. (2021). Mathematical word problem solving abilities of hearing-impaired students. Journal of Physics: Conference Series, 1778(1), 12006. https://doi.org/10.1088/17426596/1778/1/012006.

Sumalasia, I. K. Y., Suarsana, I. M., \& Astawa, I. W. P. (2020). Pengembangan bahan ajar interaktif multi representasi pada materi geometri kelas VII SMPLB Tunarungu. Pythagoras: $\quad$ Jurnal Pendidikan Matematika, 15(1). https://doi.org/10.21831/pg.v15i1.25851.

Syafrudin, T., \& Sujarwo, S. (2019). Pengembangan Bahan Ajar Untuk Pembelajaran Matematika Bagi Siswa Tunarungu. Suska Journal of Mathematics Education, 5(2), 87-94. https://doi.org/10.24014/sjme.v5i2.8170.

Tamami, A., Dan, K. D.-J. P., \& 2020, U. (2020). The Effectivity of 3D Interactive Multimedia to Increase the Students' Visuospatial Abilities in Molecular. Jurnal Pendidikan Dan Pengajaran, 307-316. https://doi.org/10.23887/jpp.v53i1.25883.

Weriyanti, W., Firman, F., Taufina, T., Taufina, T., \& Zikri, A. (2020). Pengembangan Bahan Ajar Tematik Terpadu dengan Strategi Question Student Have di Sekolah Dasar. Jurnal Basicedu, 4(2), 476-483. https://doi.org/10.31004/basicedu.v4i2.374.

Winarsih, M. (2013). Kompetensi Guru Reguler di Sekolah Inklusif dalam Pembelajaran Bagi Siswa Tunarungu. Perspektif Ilmu Pendidikan, 27(2), 97-103. https://doi.org/10.21009/pip.272.3.

Yuliana, D. W., \& Supraptono, E. (2016). Multimedia interaktif menyimak cerita tentang peristiwa di sekitar untuk siswa tunarungu. Didaktikum, 17(1). https://irpp.com/index.php/didaktikum/article/view/383. 